\title{
The Street Vendor Empowerment:
}

\author{
A Potential Factor for Culinary Tourism In Kupang City
}

\author{
Maria C. B. Manteiro*, Maria, Darwin Y. Kefi \\ Business Administration Department \\ State Polytechnic of Kupang \\ Kupang, Indonesia \\ *maria.manteiro@pnk.ac.id,m.maria66@ymail.com,darwinyopiekefi@yahoo.co.id
}

\begin{abstract}
This research is entitled the empowerment of street vendors (PKL) as a potential for culinary tourism in Kupang City. The objectives of this study are 1) To determine the existence of street vendors (PKL) as a tourism potential in Kupang City. 2) To know the concept of empowering the existence of street vendors (PKL) as a tourism potential in Kupang City. This research uses descriptive qualitative research method which is a case study on the research object, namely the 3 selected clusters, the government concerned, and consumers (visitors). The existence of street vendors itself still brings problems in the Kupang City cluster, so it is necessary to have a reengineering process, namely partnerships and business reengineering as an appropriate empowerment effort so that the existence of street vendors can become a potential culinary tourism for both local and foreign tourists.
\end{abstract}

Keywords—empowerment, street vendors, tourism, culinary

\section{INTRODUCTION}

The strategic action in improving and strengthening the economy of the largest part of the Indonesian people is by empowering Micro, Small and Medium Enterprises (MSMEs), including culinary street vendors. This is in accordance with the mandate of Law Number 20 of 2008 concerning Micro, Small and Medium Enterprises. Therefore, it is expected that MSMEs can play a major role in the process of democratization, fostering community independence, increasing welfare and reducing unemployment, reducing the number of poor people, as well as reducing income inequality.

Street Food Traders (PKL) provide several uniqueness, including the place that is offered as a means or medium of interaction between people at each level of the group. Services that raise the concept of equality of service to each customer are the main strength of this business. In addition, this trend is considered unable to overcome the threat to the existence of street vendors. The reason is, the negative image is getting stronger in street vendors because of the problems it has caused.

In fact, if developed, street vendors can become one of the strategic sectors which capable of boosting the economy in the future. According to Alma [1], street vendors can be a huge potential if they are developed properly. However, developing the potential of street vendors is challenging, considering the negative impacts caused by the street vendors' activities. These negative impacts include a reduction in the quality of the surrounding environment, loss of function of sidewalks for pedestrians, and disruption of orderliness of transportation routes. In fact, often street vendors are seen as disturbing public order. The existence of street vendors is still considered by the government to contradict the concept of urban spatial planning.

Employment conditions in Nusa Tenggara Timur province (NTT) are influenced by economic conditions and the number of jobs. According to Statistics Bureau Centre (BPS) data in 2019 there was a decrease in the labour force participation rate in August 2018, namely 70.17\% reduced by 1.67 points or 68.50 percent in August 2019 [2]. In order to maintain regional economic growth especially the city of Kupang, which needs to optimize the informal sector, one of which is the creative industry, namely street vendors (PKL). The problems faced by the government with the existence of street vendors include the loss of the function of roads and sidewalks that are disturbed (in several locations), some street vendors who still do not follow the rules of the government relating to order and security in Kupang city which are not in accordance with the concept of city administration, and there are street vendors who have not implemented good food safety and environmental sanitation.

This research used qualitative and quantitative methods in which data collection is carried out using survey methods, interviews, desk studies (street vendors and informants) and questionnaires (visitors). The same problem has also been raised by several researchers related to the role of street vendors as a potential culinary tourism, while the differences with this study are located in different locations and places and times, the research indicators developed and the data analysis tools and methods used in the study.

Looking at the problems mentioned above, the writer wants to create a model for empowering street food traders (PKL) as a potential culinary tourism in the city of Kupang. 


\section{LITERATURE REVIEW}

The street vendors in Indonesia are an alternative for laborers who are not absorbed in formal sector businesses is to open a business in the formal sector. This workforce, which amounts to $91.86 \%$, is absorbed in the formal sector by $30.51 \%$ and the remaining $68.49 \%$ is absorbed in Micro / PKL (Media Indonesia, 16 May 2009). This proves that the business alternative taken by workers who are not absorbed in formal sector business is to open a business in the informal sector. This condition is not much different from the results of the ILO research, where $35 \%$ of the Indonesian population works in the formal sector and the remaining $65 \%$ works in Micro Businesses / PKL. According to the Foreign Investment Board, it is estimated that around $70 \%$ of domestic and foreign capital is invested in Indonesia's major cities, but it only absorbs about $10-16 \%$ of the formal workforce.

Empowerment of Micro, Small and Medium Enterprises (MSMEs), including culinary street vendors, is a strategic step in improving and strengthening the economy of the largest part of the Indonesian people. This is in accordance with the mandate of Law Number 20 of 2008 concerning Micro, Small and Medium Enterprises. Therefore, it is hoped that MSMEs can play a major role in the process of democratization, growing community independence, increasing welfare and strategic factors in reducing unemployment, reducing the number of poor people, and reducing inequality in people's income.

\section{A. Empowerment}

According to Widjaja [3] community empowerment is an effort to increase the capacity and potential of the community so that people can use their maximum dignity and identity to survive and develop themselves independently in the economic, social, religious and cultural fields

\section{B. Street Vendors}

Street vendors are people with relatively little capital trying to produce and sell goods (services) to meet the needs of certain groups in society. Street vendors are generally selfemployed, meaning that the majority of street vendors only consist of one worker. The capital owned is relatively small, and is divided into fixed capital, in the form of equipment and working capital

\section{Culinary Tourism}

Culinary tourism is one or part of the cultural resources of the community. In other words, culinary tourism is a tourist activity that emphasizes "culinary" or cuisine / food as a tourism attraction.

\section{Prior Studies}

According to the results of Falih Suwaidih's research with the title of street vendor development strategy at the centre of PKL Taman Prasasti, Surabaya City, it concluded that the Street Vendors Empowerment Strategy (PKL) was in the form of technical health guidance, technical guidance on trade ethics, routine meetings, pre-operative training, contributions to savings and loan cooperatives, providing PKL visual aids and supporting infrastructure.

While the results of Rofaidas R's research with the title Concept of empowering street vendors as a potential for culinary tourism, the results of this study show that the concept of culinary tourism can be applied to boost the value of street vendors.

\section{METHODS}

The research design starts with several stages: 1. Formulate systematic questions by checking the completeness of the respondent's identity. 2. Data tabulation, performed to group data based on indicators. 3. Identification, mapping / mapping and descriptive analysis related to the profile of street vendors and current problems. 4. Identification, mapping / descriptive analysis related to government policies and empowerment that is carried out as one of the tourism potentials in Kupang City. [4]. Conducting a gap analysis between points (3) and (4) so that PKL empowerment policies can be formulated to increase tourism potential, as well as what PKL, government, companies/entrepreneurs, and university institutions can do [5]. The results of this analysis can also be used as information for the government in making policies for the needs of street vendors as a potential culinary tourism. For companies in the form of CSR and business cooperation, educational institutions are the results of research in refining the curriculum to increase the link and match between education and industrial needs [6]. Mapping and analysing the role of the 'triple helix' system (government, companies and academics) in empowering street vendors in Kupang city (Table 2).

TABLE I. THE NUMBER OF CULINARY STREET VENDORS IN THREE Cluster OF KuPANG CITY

\begin{tabular}{|c|l|c|c|}
\hline No & \multicolumn{1}{|c|}{ PKL } & Population & Sample \\
\hline 1 & Moh. Hatta Street & 15 & 3 \\
\hline 2 & Kosasi Solor Village Street & 22 & 4 \\
\hline 3 & El-Tari Street & 12 & 3 \\
\hline \multicolumn{2}{|c|}{ Total } & 50 & 10 \\
\hline
\end{tabular}

The population in this study were street vendors (PKL) in Kupang City. Sampling was done by using purposive sampling method. The sample consisted of street vendors (PKL) who sell food / drinks in three areas of Kupang city which are usually visited by buyers (consumers) at night, namely around Jalan Moh Hatta, Jalan. Kosasih Kampung Solor and El Tari street, Kupang City. The sample of street vendors was selected based on the unique characteristics of the business and has a specificity based on Creative Economic, namely the cultural aspects of 10 street vendors (Table 1).

And informants consisting of the relevant government (Kupang City PEMKOD, Cooperative Office, Industry and Trade Office, Kupang City Tourism Office) and consumers 
who visited the location during the study were 30 visitors using purposive sampling technique.

TABLE II. DATA Collection Method MatriX

\begin{tabular}{|c|l|l|}
\hline No & \multicolumn{1}{|c|}{ Variable Data } & \multicolumn{1}{|c|}{ Collection Method } \\
\hline 1 & $\begin{array}{l}\text { The problem of street cendors in } \\
\text { Kupang Cisty currently PKL } \\
\text { empowerment wich has been } \\
\text { implemented by the local } \\
\text { government studies }\end{array}$ & $\begin{array}{l}\text { Field observation, } \\
\text { survey and in-depth } \\
\text { interviews, and desk } \\
\text { studies }\end{array}$ \\
\hline 2 & $\begin{array}{l}\text { Reengining needed to empower } \\
\text { street vendors }\end{array}$ & $\begin{array}{l}\text { Field observations, } \\
\text { surveys and indepth } \\
\text { intervies questionares }\end{array}$ \\
\hline 3 & $\begin{array}{l}\text { Policies related to empowering } \\
\text { street vendors to increase tourism } \\
\text { potential in Kupang City }\end{array}$ & $\begin{array}{l}\text { Destification and expert } \\
\text { justifican }\end{array}$ \\
\hline
\end{tabular}

\section{RESULTS}

Street vendors in the culinary sector have an important role in the economy both in macro and micro aspects. From a socioeconomic perspective, culinary street vendors in Kupang City tend to increase along with the increasingly varied consumer demands.

\section{A. The Existence of Street Vendors in the Location of Moh Hatta Street}

Street vendors on Jalan Sudirman, Kupang are one of the most visited places because of their strategic location close to the city centre such as hotels, hospitals, schools and shopping centres. The majority of street vendors sell various types of food and beverages such as fried rice, fried noodles, grilled pork rice, meatballs / soup and various drinks. The existence of street vendors on Jalan Moh Hatta resulted in a narrowing of the function areas of roads and sidewalks which were used as land for selling and there was no parking space for buyers, resulting in traffic jams.

\section{B. The Existence of Street Vendors on Kaosasih, Solor Village Street}

Located in the centre of the city, the culinary business owners in this place come from various tribes so that there is a diversity of food menus that are served and can be enjoyed. The uniqueness offered in this place is enjoying culinary in an open tent and this culinary tour can only be enjoyed at night. The existence of street vendors does not cause traffic jams because they are on one of the roads provided by the city government to sell at night starting from 17.00-23.00. Problems that arise at the street vendor locations include environmental sanitation problems due to the absence of disposal. The disposal of wastewater from street vendors (washing dishes) so that it produces an unpleasant door around the location. Even though the location is one of the centres of culinary tourism where both domestic and foreign tourists often visit there to enjoy the fresh seafood. Some of the production activities that are still carried out by street vendors at their business premises are suspected to be the cause of environmental pollution in this area.

\section{The Existence of Street Vendors on Eltari Street}

A street vendor with a unique product, namely grilled corn snacks typical of Kupang with a different taste because it is served with sambal luat (one of the typical sambal in NTT). Its strategic location makes El Tari's roasted corn crowded to be visited by corn connoisseurs and at the same time as a place for family and young people to chat, especially on Saturday nights and become one of the culinary centres of Kupang city. The same problem that arises is the loss of function of the sidewalks due to street vendors selling roasted corn parked their carts on the sidewalk so that pedestrians passing the main El Tari road had to go down to the main road even though this route is one of the fast lanes in Kupang City.

In addition, the existence of street vendors is still debatable for some people. From the author's interviews with several customers that the street vendors in the 3 clusters help them to fulfil their food and recreational wants and needs because according to them the products are sold at affordable prices, serving fast and strategic location. This opinion also contradicts some consumers who enjoy food, there are concerns from them about the cleanliness of food and the quality of washing water for materials and food utensils such as water for cleaning grilled fish that will be processed and water for washing dishes and glasses (Sudirman road cluster and Kosasih road cluster) .

\section{Weaknesses and Strengths of Street Food Trader Business Concept in Kupang City in 3 Clusters}

Basically, the main strength of PML in the 3 clusters is the business location which is located in the economic centre of Kupang City. The business implements the concept of being closer to consumers is the main strength of them. The humble place and equal service to each consumer add to its own appeal to PMKL. In addition, cost leadership is an attraction for consumers from all walks of life who want to have a culinary tour.

From an economic perspective, the main strength of street vendors is price. Offering products at low prices is a street vendor strategy in reaching their customers. The low price of the product is due to the emphasis on cost efficiency. This emphasizes on cost efficiency is carried out on several cost aspects, including: (1) fixed costs which include building and land costs, advertising and promotion costs, tools and equipment, and (2) variable cost efficiency which includes labour, material costs (medium quality), and semi-variable costs (such as water, electricity, cooking oil, and so on.

From the social aspect, street vendors are able to transform into media or means of community interaction. Consumers who consist of various levels of groups, children, adolescents, to adults are able to build conditions of socialization in society. Services that elevate the concept of equality (equality) or equality of service to each customer are the main strength for this business. Thus, street vendors can be a means of building relationships for a number of people. 
The weaknesses include:

- The public perception that food from street vendors is a product of economies of scale. This is due to the relatively low price of the food and the way it is served.

- Lack of variation in the product presented. One of the reasons is the limited capital they have.

- The lack of innovation and creativity of street vendors makes product development very difficult.

- There is still a lack of guaranteed product safety standards,

- The quality of the location and environment, poor management of business waste has an impact on the quality of the business environment. The neighbourhood that looks slum is increasingly decorating the locations and places of business of street vendors.

- The principle of prime service is not yet implemented. Most of the street vendors still do not understand the concept of excellent service to consumers fundamentally. Educational background and lack of ethics are the contributing factors.

- Limited capital is the cause of the lack of existing facilities and infrastructure on site.

- Difficulties in obtaining loan assistance from financial institutions, such as the convoluted process in terms of borrowing.

\section{E. Empowerment Efforts That Have Been Done}

Efforts to organize street vendors, or PKL, in Kupang city are still being carried out and are still facing several obstacles. Apart from the problem of places for relocation, it turns out that the Kupang City Government also finds it difficult to curb street vendors in several places. This can be seen from the chaos that often occurs between Satpol PP of Kupang City and street vendors in the Sudirman street cluster. In addition, the cooperative and UMKM offices also stated that sometimes it was difficult to roll out programs for PKL who were considered less active because several things such as the assistance given were used for other needs not for business. According to the Kupang City Cooperative and UMKM office, efforts to organize street vendors around the 3 clusters have been carried out, such as sales cart assistance for several street vendors and management training. However, the lack of participation from the street vendors is an obstacle to these programs.

From interviews with related government officials, there is a discourse from the government to provide relocation sites and facility assistance for street vendors to be more orderly but for now it is still conflicting with funds and is still building synergies between the government and private institutions / companies (CSR). NGOs and higher education for support the success of street vendors so that they can become one of the potential culinary tourism in the city of Kupang.

\section{F. Culinary Tourism Empowerment Concept}

The concept of culinary tourism was first introduced by Long [7] in order to explain his experience of the culinary existence of other communities that caught his attention. PKL empowerment is a tourism concept aimed at making PMKL as a support for other tourism in the area. This is in line with what Kirshenblatt-Gimblet [8] stated that food or cuisine is important for various types of tourism (natural, cultural, and special interests) because everyone definitely needs food.

From the interviews of 30 visitor respondents in 3 clusters, there are several factors that influence visitors to go on a culinary tour to street vendors, including taste and quality being the top priority (25\%), followed by cleanliness and product safety (19\%), accessibility \& amenities ( facilities around culinary attractions) $12 \%$, service $(8 \%)$ and price and appearance $(6 \%)$ are the last points because according to consumers low prices are no longer the main points. Mindset change and improvement purchasing power of the public (consumers) is one of the factors causing this change in behaviour. Therefore, it is necessary to have a business replanning concept involving entrepreneurs and the government to support the concept of culinary tourism.

\section{G. Business Reengineering}

Reformulation of business strategies needs to be done starting from redesigning business management, such as the existence of periodic business financial reports and marketing strategies with product differentiation strategies. So, street vendors can try to produce products that have value in themselves and not products of adoption.

1) Standard operating procedure: There needs to be a clear discussion of the standard operating system of the street vendors which ensures comfort between the parties concerned. In general, the PKL business process consists of: 1) Purchasing raw materials, 2) Storage of raw materials, 3) Production processes, 4) Washing tools and materials, 5) Packaging, 6) Delivery of finished goods. $-3,4$ th, 5th, and 6th are still carried out at the place of business and outside the place of business. This will reduce the waste generated and increase the speed of service to customers.

2) Service quality improvement: Service quality is an added value in a culinary business. The fact is that some PMKL still do not clearly understand good services to consumers.

3) Product safety label: Supervision of street vendors is deemed necessary considering the risks that can be caused by unsafe products for consumption. Therefore, cooperation between government agencies needs to be done in an effort to increase supervision of PKL products. To increase supervision of products from street vendors, business licensing should 
include a product safety label which is based on a product safety test for consumption.

4) Location management and environment: Given the possibility of contamination of street vendors' products from hazardous substances caused by air pollution, it is necessary to provide special locations for street vendors.

5) Partnership as a culinary tourism concept support: Partnership is a business strategy carried out by two or more parties within a certain period of time to gain mutual benefits with the principle of mutual need and mutual growth. Marketing within the scope of the partnership concerns the price and guarantees of the partner company in purchasing the production output produced by the partner group.

In the matter of developing the concept of culinary tourism, street vendors cannot stand alone but there is a need to develop strong partnerships with various parties including: The government acts as the authority for business permits and arrangements for street vendors. The government can also become a facilitator as a PKL development as a Small and Medium Enterprise (UKM), the program can be in the form of disbursement of capital, training, and other developments. The reciprocity that is obtained are:

- Tax fees for local income.

- Suppliers. Suppliers are the most important part of business sustainability because they play a role in supplying raw materials, including suppliers of fish, vegetables, meat, and other necessities.

- In the business world, Corporate Social Responsibility (CSR) is a milestone in building the strength of entrepreneurship sustainability. The company also needs the CSR distribution media. Street vendors can be such media.

- State Polytechnic of Kupang. As one of the formal educational institutions that is responsible for the progress of the NTT community. One of the main activities of higher education is community service. The activity is providing assistance through trainings in accordance with the available competencies.

\section{CONCLUSION}

- Street vendors in Kupang City are scattered in several areas of the city of Kupang, Clusters in the area of Jalan Sudirman, Jalan Kosasih and Jalan El Tari are 3 favourite places for street vendors and consumers because of their strategic location in the centre of the city.

- The increasing presence of street vendors in the 3 selected clusters caused problems, including reduced road function, loss of pedestrian facilities, and decreased environmental quality around the location.

- The main strength of the street vendors in the 3 selected clusters is the business location in the centre of the economy. Apart from its strategic location and cost leadership which is an attraction for consumers to visit the street vendor locations. From the social aspect, PML is able to become a medium or medium for community interaction. Consumers who consist of various levels of groups, children, adolescent, to adults.

- The related government, especially the Kupang City Cooperative Office and the Municipal Government, have made various efforts, including the arrangement of street vendors, especially in the locations of Jalan Kosasih and Sudirman. Providing train assistance for street vendors at the El Tari street location and providing trainings. However, the problem faced is the lack of participation from the street vendors, among others, not implementing a bookkeeping and cleaning system.

- The concept of culinary tourism can be applied to increase the value of PMKL's existence. PKL is expected to encourage additional per capita income for Kupang City as the City Centre of East Nusa Tenggara Province. PKL based on culinary tourism potential can be achieved through Business Process Reengineering without eliminating the uniqueness of the street vendor business. The redesign of the sidewalk business will refer to several main points: setting the Standard Operating Procedure, monitoring product safety standards through labelling / special certificates for street vendors, location and environmental management, improving services, and providing supporting and supporting facilities and infrastructure. the concept of partnership in the development of street vendors culinary tourism, partnership programs need to be carried out by stakeholders, namely: relevant governments, financial institutions, NGOs, suppliers / agents, companies / private parties and educational institutions (State Polytechnic of Kupang).

\section{RECOMMENDATION}

For the development of street vendors (PKL) in Kupang City, it is necessary to have a coordination between all related parties. PKL as an informal sector plays an important role in the progress of the Kupang area, therefore PKL is expected to be able to follow government regulations and apply the SOP that has been enforced. Street vendors are also obliged to pay attention to the quality and cleanliness of food as well as places so that they can attract tourists to visit. Empowerment of street vendors in the culinary sector as a tourism potential should also be collaborated in other informal sectors such as collaboration between event organizers to create events at street vendors on certain days so as to attract local and foreign tourists.

\section{REFERENCES}

[1] B. Alma, Kewirausahaan, Bandung: Penerbit CV Alfabeta, 2011.

[2] Badan Pusat Statistik Kota Kupang, 2019. 
[3] H.A.W. Widjaja, Otonomi Desa: Merupakan Otonomi yang Asli, Bulat dan Utuh, Bandung: PT. Raja Grafindo Persada, 2003.

[4] S. Arikunto, Prosedur penelitian suatu pendekatan praktik, Jakarta: PT. Rineka Cipta, 2010.

[5] Basrowi dan Suwandi, Memahami Penelitian Kualitatif, Jakarta: PT. Penerbit Rineka Cipta, 2008.
[6] Jumhur, "Model Pengembangan Pedagang Kaki Lima (PKL) di Kota Singkawang," Jurnal Ekonomi Bisnis dan Kewirausahaan, vol. 4, no. 1, pp. 125-139, 2015.

[7] E. Wolf, "Culinary Tourism: The Hidden Harvest," International Culinary Tourism Association, 2006.

[8] B. Kirshenblatt-Gimblet, "Playing to the senses: food as performance medium,” Performance Journal, vol. 4, no. 1, pp. 1-30, 1999. 